\title{
Keefektifan Model Pembelajaran Course Review Horay berbantu Media Kartu Pintar terhadap Hasil Belajar IPS
}

\author{
Rizki Oktaviani ${ }^{1^{*}}$, Rahmat Sudrajat ${ }^{2}$, Arfilia Wijayanti ${ }^{3}$ \\ 1,2,3 Fakultas Ilmu Pendidikan, Universitas PGRI Semarang , Indonesia
}

\section{A R T I C LEINFO \\ Article history: \\ Received 18 Desember 2017 \\ Received in revised form 30 Desember 2017 \\ Accepted 15 Januari 2018 \\ Available online 20 \\ Februari 2018}

\section{Kata Kunci:}

model $C R H$, hasil belajar

Keywords:

CRH model, learning

outcomes

\begin{abstract}
A B S T R A K
Penelitian ini bertujuan untuk mengetahui keefektifan model pembelajaran Course Review Horay berbantu media kartu pintar terhadap hasil belajar IPS kelas V SDN Sumberarum Jaken Pati. Jenis penelitian ini adalah penelitian kuantitatif dengan desain Pre Eksperimental Design dan jenis yang diambil adalah One-Group Pretest-Posttest Design. Sampel yang diambil adalah 16 siswa kelas V dengan menggunakan teknik Non Probability Sampling dengan sampling jenuh. Penelitian diperoleh ratarata nilai pretest sebesar 46,25 sedangkan rata-rata nilai posttest sebesar 81,5 . Berdasarkan analisis data pada perhitungan uji $t$ diperoleh $t_{\text {hitung }}=6,25$ dan $t_{\text {tabel }}=1,753$. Karena $t_{\text {hitung }}>t_{\text {tabel }}$ yaitu 6,25>1,753 maka sesuai dengan rumusan hipotesis yang diujikan, $\mathrm{H}_{0}$ ditolak dan $\mathrm{H}_{\mathrm{a}}$ diterima. Bahwa model pembelajaran Course Review Horay berbantu media kartu pintar efektif terhadap hasil belajar IPS kelas V SDN Sumberarum Jaken Pati.
\end{abstract}

\section{A B S T R A C T}

This study aims to determine the effectiveness of the Course Review Horay learning model assisted by smart card media on social studies learning outcomes in grade V SDN Sumberarum Jaken Pati. The type of this research is quantitative research with the design of Pre Experimental Design and the type taken is One-Group Pretest-Posttest Design. The samples taken were 16 class V students using the Non Probability Sampling technique with saturated sampling. The research obtained the average pretest value of 46.25 while the average posttest value was 81.5. Based on data analysis on the calculation of the $t$ test obtained thitung $=6.25$ and t table $=1.753$. Because tcount $>t$ table is $6.25>1.753$ then according to the formulated hypothesis tested, $\mathrm{HO}$ is rejected and $\mathrm{Ha}$ is accepted. That the Course Review Horay learning model is assisted by smart card media effective on social studies learning outcomes in grade $V$ at SDN Sumberarum Jaken Pati. 


\section{Pendahuluan}

Pendidikan merupakan aspek yang sangat berperan dalam pembangunan suatu bangsa. Menurut UU RI No 20 Tahun 2003 menyatakan bahwa pendidikan adalah usaha sadar dan terencana untuk mewujudkan suasana belajar dan proses pembelajaran agar peserta didik secara aktif mengembangkan potensi dirinya untuk memiliki kekuatan spiritual keagamaan, pengendalian diri, kepribadian, kecerdasan, akhlak mulia, serta keterampilan yang diperlukan dirinya, masyarakat, bangsa dan negara. Pendidikan memegang peranan yang sangat penting di berbagai sektor kehidupan. Tujuan pendidikan tersebut akan tercapai apabila guru mampu menciptakan suatu proses pembelajaran yang optimal sehingga siswa mencapai hasil belajar sesuai KKM (Kriteria Ketuntasan Minimal) atau bahkan lebih.

Pembelajaran yang baik dapat ditunjang dari pemilihan strategi yang tepat mampu menciptakan suasana pembelajaran yang yang menyenangkan, menarik minat dan antusias belajar, serta suasana yang kondusif. Pada kenyataannya, kesiapan dan antusias siswa selama mengikuti pembelajaran masih kurang sehingga berpengaruh pada hasil belajar siswa.

Permasalahan dilapangan yang terjadi pada kelas V SD Negeri Sumberarum Jaken Pati diantaranya penggunaan model pembelajaran ceramah dalam kegiatan pembelajaran dan siswa kurang aktif selama pembelajaran berlangsung, hal tersebut tidak sesuai dengan tujuan pendidikan yang termuat dalam UU No. 20 Th. 2003 pasal 1, yang mengakibatkan hasil belajar siswa tidak sesuai harapan atau tuntas KKM khususnya pada mata pelajaran IPS. Pada dasarnya pendidikan IPS berhubungan erat dengan pengetahuan, keterampilan, sikap, dan nilai-nilai dalam rangka berpartisipasi di dalam masyarakat, negara, dan bahkan didunia (Banks dalam Susanto, 2013: 141). Karakterisitik mata pelajaran IPS menurut wali kelas V SD Negeri Sumberarum Jaken Pati, IPS merupakan mata pelajaran yang menuntut siswa untuk menghafal (hafalan) dikarenakan materi dari IPS tersebut bersifat abstrak sehingga siswa seusia kelas V SD yang tahapan berpikirnya masih dalam tahapan berpikir secara konkret terkadang mengalami kesulitan dalam memahami materi-materi IPS tersebut.

Berdasarkan hasil kegiatan wawancara menunjukkan bahwa motivasi membaca siswa masih rendah, siswa kurang aktif dalam pembelajaran sehingga hasil nilai ulangan harian rendah. Dalam pembelajaran dominan menggunakan model pembelajaran konvensional, dan pembelajaran belum menggunakan media pembelajaran. Oleh karena itu, diperlukan suatu penelitian yang memberikan inovasi pembelajaran dengan suasana belajar yang lebih menarik, interaktif, menyenangkan karena peserta didik dapat bermain bersama serta memberikan ruang untuk berpartisipasi aktif dalam pembelajaran yang efektif

Untuk mengatasi permasalahan yang terjadi, diperlukan upaya untuk memperbaiki kualitas pembelajaran agar dapat meningkatkan keaktifan dan partisipasi siswa sehingga proses pembelajaran IPS berjalan efektif. Salah satu alternatif yang digunakan yaitu dengan menerapkan model pembelajaran kooperatif Course Review Horay. Model pembelajaran kooperatif tersebut dirancang untuk mendorong siswa berpartisipasi dalam pembelajaran IPS.

Huda (2013: 229) menjelaskan bahwa Course Review Horey merupakan model pembelajaran yang dapat menciptakan suasana kelas menjadi meriah dan menyenangkan. Model ini membantu siswa untuk memahami konsep dengan baik melalui diskusi. Untuk mengatasi permasalahan yang terjadi, diperlukan upaya untuk memperbaiki kualitas pembelajaran agar dapat meningkatkan keaktifan dan partisipasi siswa sehingga proses pembelajaran IPS berjalan efektif. Salah satu alternatif yang digunakan yaitu dengan menerapkan model pembelajaran kooperatif Course Review Horay. Model pembelajaran kooperatif tersebut dirancang untuk mendorong siswa berpartisipasi dalam pembelajaran IPS.

Shoimin (2014: 54) menjelaskan bahwa "Model pembelajaran Course Review Horay merupakan salah satu pembelajaran kooperatif, yaitu kegiatan belajar mengajar dengan cara pengelompokan siswa ke dalam kelompok-kelompok kecil. Pembelajaran ini merupakan suatu pengujian terhadap pemahaman konsep siswa menggunakan kotak yang diisi dengan soal dan diberi nomor untuk menuliskan jawabannya. Siswa yang paling terdahulu mendapatkan tanda benar langsung berteriak horay atau yel-yel lainnya.

Hal tersebut dikuatkan hasil penelitian dalam jurnal oleh Yanti Ari Krisna pada tahun 2013 dengan judul "Pengaruh Model Pembelajaran Course Review Horay Terhadap Kemampuan Berpikir Kritis Mata Pelajaran IPS Siswa Kelas V SD Di Gugus V Kecamatan Kediri". Dalam penelitian diperoleh thitung $=6,4$ dan $t_{\text {tabel }}=1,684$ dengan taraf signifikansi $5 \%$. Berdasarkan kriteria pengujian, karena $t_{\text {hitung }}>t_{\text {tabel }}$ maka $\mathrm{H}_{0}$ ditolak dan $\mathrm{H}_{\mathrm{i}}$ diterima. Sehingga dapat dikatakan bahwa model pembelajaran Course Review Horay berpengaruh terhadap hasil belajar IPS Kelas V SD di Gugus V Kecamatan Kediri.

Menurut Huda (2013: 231) model pembelajaran Course Review Horay mempunyai kekurangan bahwa penyamarataan nilai antara siswa yang pasif dan aktif, serta dapat mengganggu suasana belajar 
kelas lain. Sehingga untuk menutupi kekurangan model pembelajaran Course Review Horay, peneliti menerapkan model pembelajaran Course Review Horay berbantu media kartu pintar.

Media kartu pintar adalah suatu alat atau media yang berupa kartu dengan background berwarna yang berisi materi serta gambar yang dapat digunakan dalam pembelajaran IPS. Arsyad (2014:109) mengatakan bahwa media gambar memiliki fungsi utama yaitu memvisualisasikan konsep yang ingin disampaikan kepada siswa. Sehingga dengan menggunakan media visual dapat membantu siswa memperjelas konsep atau materi yang abstrak. Selain itu, media visual banyak dipilih oleh guru karena media visual sangat mudah digunakan dan juga mudah didapatkan. Salah satu media pembelajaran yang dapat digunakan adalah media kartu pintar.

Media kartu pintar dipilih oleh peneliti sebagai sarana penunjang yang telah disesuaikan dengan sintaks model pembelajaran Course Review Horay yang menggunakan kartu yang berisi materi mengenai pembelajaran. Dengan menggunakan media kartu pintar maka siswa akan termotivasi untuk belajar dan membaca dengan menyenangkan tidak jenuh karena penjelasan materi yang tidak terlalu banyak disertai dengan gambar. Pelaksanaan dalam pembelajaran dengan media kartu ini lebih mudah mengarah pada sistem belajar sambil bermain.

Media kartu pintar dapat digunakan untuk menutupi kekurangan model pembelajaran Course Review Horay yaitu penyamarataan nilai antara siswa yang pasif dan aktif. Dengan berbantu media kartu pintar, setiap siswa mendapatkan satu kartu dengan materi yang sama sehingga dalam mengerjakan soal evaluasi dikerjakan secara individu serta setiap siswa dalam satu kelompok tetap menulis jawabannya masing-masing pada lembar jawab. Penggunaan media kartu pintar dapat membuat siswa fokus karena pada media kartu pintar terdapat gambar dan penjelasan materi yang tidak terlalu banyak.

Media kartu pintar yang akan dikembangkan oleh penulis adalah menyesuaikan dengan materi usaha kegiatan ekonomi di Indonesia dan contohnya, berisi materi dan gambar yang dibuat berdasarkan agar siswa dapat memahami materi dan aktif di depan kelas. Berdasarkan hasil yang telah dijabarkan dan disajikan, maka peneliti melakukan penelitian dengan judul Keefektifan Model Pembelajaran Course Review Horay Berbantu Media Kartu Pintar Terhadap Hasil Belajar IPS Siswa Kelas V SDN Sumberarum Pati.

\section{Metode}

Penelitian ini dilakukan di SD Negeri Sumberarum Kecamatan Jaken, Kabupaten Penelitian disasarkan pada semester ganjil kelas V tahun ajaran 2018/2019 yang terdiri dari 16 siswa, pada tanggal 21-29 November 2018. Penelitian ini adalah penelitian kuantitatif dengan desain Pre Eksperimental Design dan jenis yang diambil adalah One Group Pretest Posttest Design. Pretest digunakan untuk mengetahui kondisi awal pada siswa sebelum diberi perlakuan dan setelah itu diberi perlakuan, setelah diberi perlakuan siswa diberi Posttest.

Tabel 1. Rancangan Desain One-Group Pretest Posttest Design

\begin{tabular}{clll}
\hline Kelompok & Tes & Perlakuan & Tes \\
\hline Siswa Kelas V & Pretest & Pembelajaran & Posttest \\
& menggunakan & \\
& model & \\
& Pembelajaran Course Review & \\
& Horay berbantu media kartu & \\
& pintar & \\
\hline
\end{tabular}

Teknik pengumpulan data yang digunakan dalam penelitian ini yaitu tes. Instrumen menggunakan tes (Pretest-Posttest) berupa tes pilihan ganda. Wawancara terstruktur, obervasi dan dokumentasi yang dilakukan dalam kegiatan pembelajaran dikelas.

\section{Hasil dan Pembahasan}

Penelitian ini adalah penelitian kuantitatif dengan desain Pre Eksperimental Design dan jenis yang diambil adalah One Group Pretest Posttest Design. Data penelitian ini terdiri dari data awal yang diperoleh dari nilai pretest dan data akhir yang diperoleh dari nilai posttest. Untuk menentukan instrumen penelitian maka diperlukan uji coba soal instrumen pada soal pretest dan posttest. Uji coba pada instrumen ini berjumlah 30 butir soal berbentuk pilihan ganda. Kemudian soal tersebut diujikan kepada 
siswa, setelah dilakukan uji coba soal instrumen kemudian hasil uji coba tersebut diuji dengan uji validitas, reliabilitas, taraf kesukaran, dan daya pembeda. Sehingga dapat diketahui soal yang valid. Pretest merupakan data awal yang diperoleh sebelum siswa diberi perlakuan dengan menggunakan model pembelajaran Course Review Horay berbantu media kartu pintar. Posttest merupakan data akhir yang diperoleh setelah siswa diberi perlakuan dengan menggunakan model pembelajaran Course Review Horay berbantu media kartu pintar.

Dari hasil penelitian di peroleh dari nilai pretest dan posttest. Nilai pretest dan posttest dinyatakan tuntas jika mengalami peningkatan memenuhi KKM serta adanya peningkatan serta adanya peningkatan nilai dari pretest dan posttest setelah diberikan perlakuan hasilnya berbeda. Berikut tabel penjelasan mengenai data hasil pretest dan posttest kelas V SDN Sumberarum Jaken Pati 2018/2019 dapat dilihat pada Tabel 2.

Tabel 2. Data Hasil Pretest dan Posttest

\begin{tabular}{ccc}
\hline Kategori & Pretest & Posttest \\
\hline Nilai terendah & 25 & 65 \\
Nilai tertinggi & 80 & 95 \\
Rata-rata & 46,25 & 81,5 \\
Jumlah siswa yang tidak tuntas & 13 & 2 \\
Jumlah siswa yang tuntas & 3 & 14 \\
Presentase ketuntasan & $18,75 \%$ & $87,5 \%$ \\
\hline
\end{tabular}

Berdasarkan Tabel 2 terdapat perbedaan antara nilai terendah, nilai tertinggi, dan rata-rata. Nilai Pretest yang diperoleh siswa sangat rendah yaitu rata-rata kelas hanya 46,25 dan persentase ketuntasan hanya mencapai $18,75 \%$ sehingga siswa tidak memenuhi KKM. Sedangkan hasil Posttest rata-rata kelas mencapai 81,5 dan persentase ketuntasan mencapai 87,5\%. Jadi nilai Posttest lebih tinggi dibandingkan dengan nilai Pretest. Berdasarkan data yang diperoleh nilai terendah pada saat Pretest yaitu 25 dan nilai tertinggi 80. Hal ini disebabkan karena belum menggunakan model pembelajaran yang sesuai dengan karakteristik siswa dan belum menggunakan media pembelajaran yang sesuai dengan materi pembelajaran. Setelah pemberian perlakuan dengan menggunakan model pembelajaran Course Review Horay berbantu media Kartu Pintar dapat dilihat hasil Posttest nilai terendah 65 dan nilai tertinggi 95. Hal ini merupakan hasil perlakuan menggunakan model pembelajaran Course Review Horay berbantu media Kartu Pintar sehingga hasil belajar siswa meningkat.

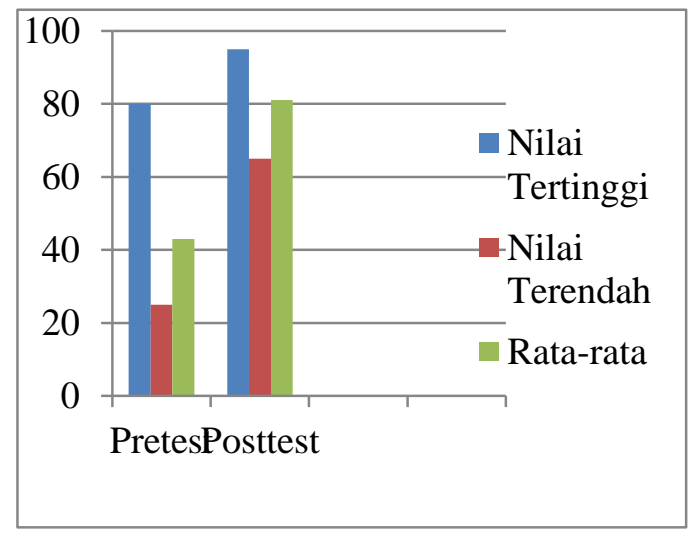

Gambar 1. Diagram nilai tertinggi, nilai terendah dan rata-rata

Berdasarkan diagram 1 dapat diketahui bahwa hasil pretest dan posttest menunjukkan bahwa terdapat peningkatan antara pretest yang sebelum diberikan perlakuan dengan nilai posttest yang sudah diberikan perlakuan dengan strategi Card Sort berbantu media gambar serta ketuntas mencapai KKM. Setelah mendapatkan data hasil pretest dan posttestakan dilakukan pengujian hipotesis. 
Tabel 3. Hasil Uji normalitas Awal

\begin{tabular}{llll}
\hline Kelas & $\mathrm{N}$ & $\mathrm{L}_{0}$ & Kesimpulan \\
\hline \multirow{3}{*}{ Responden } & & Karena $\mathrm{L}_{0}<\mathrm{L}_{\text {tabel }}$ yaitu $0,1599<$ \\
& \multirow{2}{*}{16} & 0,1599 & 0,213 maka \\
& & $\mathrm{H}_{0}$ diterima, dan data \\
& & berdistribusi normal. \\
\hline
\end{tabular}

Sumber: Data Hasil Penelitian (2018)

Berdasarkan tabel 3 hasil uji nomalitas awal (pretest) setelah mencari harga Ltabel dari nilai kritis uji liliefors dengan taraf signifikan $\alpha=5 \%$ dan $n=16$ diperoleh Ltabel $=0,213$. Sehingga dapat disimpulkan bahwa $L 0<$ Ltabel yaitu: 0,1599<0,213 maka $\mathrm{H}_{0}$ diterima. Hasil uji normalitas menunjukkan bahwa data pretest siswa berasal dari populasi yang berdistribusi normal.

Tabel 4. Hasil Uji Normalitas Akhir

\begin{tabular}{llll}
\hline Kelas & $\mathrm{N}$ & $\mathrm{L}_{0}$ & Kesimpulan \\
& & & Karena $\mathrm{L}_{0}<\mathrm{L}_{\text {tabel }}$ yaitu $0,1297<$ \\
Responden & \multirow{2}{*}{16} & 0,1297 & $\begin{array}{l}0,213 \text { maka } \mathrm{H}_{0} \\
\text { diterima, dan data berdistribusi } \\
\end{array}$ \\
& & normal. \\
\hline
\end{tabular}

Sumber: Data Hasil Penelitian (2018)

Berdasarkan tabel 4 hasil uji nomalitas akhir (posttest) setelah mencari harga Ltabel dari nilai kritis uji liliefors dengan taraf signifikan $\alpha=5 \%$ dan $n=16$ diperoleh Ltabel $=0,213$. Sehingga dapat disimpulkan bahwa $L_{0}<L_{\text {tabel }}$ yaitu: $0,1297<0,213$ maka $\mathrm{H}_{0}$ diterima. Hasil uji normalitas menunjukkan bahwa data pretest siswa berasal dari populasiyang berdistribusi normal.

Dari perhitungan uji tengan $\mathrm{db}=\mathrm{N}-1=15$ dan taraf $\alpha=0,05$ adalah 1,753. Diperoleh thitung> ttabel yaitu 6,25>1,753 maka H0 ditolak dan Ha diterima Jadi dapat disimpulkan bahwa ada perbedaan nilai rata-rata pretest dengan nilai rata-rata posttest pada hasil belajar IPS siswa kelas V SDN Sumberarum Jaken Pati. Sehingga Model Pembelajaran Course Review Horay Berbantu Media Kartu Pintar Efektif Terhadap Hasil Belajar IPS Kelas V SDN Sumberarum Pati. Sehingga dapat dikatakan bahwa ada perbedaan antara nilai rata-rata pretest dan posttest.

Ketuntasan hasil belajar posttest lebih tinggi daripada hasil belajar prtest yaitu ditunjukkan dengan rata-rata ketuntasan belajar nilai posttest 81,5 dan rata-rata nilai pretest 46,25. Berdasarkan hal tersebut dapat disimpulkan model Course Review Horay berbantu media kartu pintar efektif terhadap hasil belajar IPS pada siswa kelas V SDN Sumberarum Jaken Pati

\section{Simpulan dan Saran}

Berdasarkan hasil penelitian dan analisis dan pembahasan hasil penelitian, maka peneliti membuat kesimpulan bahwa proses pembelajaran menggunakan model model Course Review Horay berbantu media kartu pintar efektif terhadap hasil belajar IPS pada siswa kelas V SDN Sumberarum Jaken Pati. Hal ini dibuktikan dengan uji hipotesis dengan menggunakan uji t, diperoleh thitung $>$ ttabel yaitu 6,25>1,753 maka H0 ditolak dan H1 diterima. T tabel ditentukan dengan $\mathrm{db}=\mathrm{N}-1=15$ dan taraf $\alpha=0,05$ adalah 1,753. Jadi dapat disimpulkan bahwa ada perbedaan nilai rata-rata pretest dengan nilai rata-rata posttest pada hasil belajar IPS siswa kelas V SDN Sumberarum Jaken Pati. Ketuntasan hasil belajar posttest lebih tinggi daripada hasil belajar prtest yaitu ditunjukkan dengan rata-rata ketuntasan belajar nilai posttest 81,5 dan rata-rata nilai pretest 46,25. Berdasarkan hal tersebut dapat disimpulkan model Course Review Horay berbantu media kartu pintar efektif terhadap hasil belajar IPS pada siswa kelas V SDN Sumberarum Jaken Pati.

\section{Daftar Rujukan}

Arsyad, Azhar. 2014. Media Pembelajaran. Jakarta: Rajawali Pers.

Agung, A. A. Gede. 2010. Pengantar Evaluasi Pendidikan. Singaraja: Universitas Pendidikan Ganesha. 
Al-Lamri S. Ichas Hamid \& Ichas Tuti Istianti. 2006. Pengembangan Pendidikan Nilai Dalam Pembelajaran Pengetahuan Sosial di Sekolah Dasar. Bandung: Departemen Pendidikan Nasional.

Anggraeni, Desi. 2011. “Peningkatan Kualitas Pembelajaran IPS Melalui Model Pembelajaran Kooperatif Course Review Horay Pada Siswa Kelas IV SD Negeri Sekaran 01 Semarang”. Tersedia pada http://journal.unnes.ac.id/nju/index.php/kreatif/article.download/1887. Diakses tanggal 10 Desember 2012.

Budiono, dkk. 2010. "Strategi Memanfaatkan Media Gambar Untuk Meningkatkan Kemampuan Kosakata Pada Pembelajaran Bahasa Inggris Pada Sekolah Dasar". Tersedia pada http://tpcommunity05.blogspot.com/2008/05/strategi-memanfaatkan-media-gambar.html. Diakses tanggal 21 Desember 2012.

Hamalik, Oemar. 2007. Proses Belajar Mengajar. Jakarta: PT Bumi Aksara

Huda, Miftahul. 2013. "Model-Model Pengajaran dan Pembelajaran". Yogyakarta: Pustaka Pelajar.

Mudarsa. 2011. Pengaruh Model Pemblajaran Starter Eksperimendan Kbiasaan Belajar Terhadap Prestasi Belajar IPA Siswa Kelas VIII SMP N. 2 Bebandam. Jurnal Ilmiah. Singaraja: Universitas Pendidikan Ganesha.

Undang-undang Republik Indonesia Nomor 20 Tahun 2003 tentang Sistem Pendidikan Nasional. http://www.uusisdiknas.com/ Diakses pada tanggal 19 September 2018

Shoimin, Aris. 2014. 68 Model Pembelajaran Inovatif dalam Kurikulum 2013. Yogyakarta: Ar-ruzz Media.

Susanto, Ahmad. 2014. Pengembangan Pembelajaran IPS di Sekolah Dasar. Jakarta: Prenada Media Grup.

Sudjana. 2006. Metodologi Penelitian Pendidikan. Surabaya: Usaha Nasional.

Widyatun, Diah. 2012. "Model Pembelajaran Course Review Horay". Tersedia pada http://jurnalbidandiah.com/2012/04/model-pembelajaran-course-review-horay.html. Diakses tanggal 10 Desember 2012.

Yanti, Ari Krisna. 2013. "Pengaruh Model Pembelajaran Course Review Horay Terhadap Kemampuan Berpikir Kritis Mata Pelajaran IPS Siswa Kelas V Sd Di Gugus V Kecamatan Kediri". Jurnal Mimbar PGSD UNDHIKSA. http://id.portalgaruda.org/?ref=browse\&mod=viewarticle\&article=105326 Diakses pada 16 Oktober 2018 (Vol:1 Tahun 2013) 